\title{
PENGARUH KOMITMEN ORGANISASIONAL DAN PERILAKU KEPEMIMPINAN TERHADAP KUALITAS PELAYANAN BANK NTT
}

\author{
Elsye Selviana Lie \\ Program Magister Ilmu Administrasi Universitas Nusa Cendana \\ Jl. Adi Sucipto Penfui Kupang, Nusa Tenggara Timur \\ Email : elsyeselvianalie@yahoo.co.id
}

\begin{abstract}
ABSTRAK
Adapun tujuan dari penelitian ini adalah : (1) mendeskripsikan peranan Bank NTT dalam pembangunan di NTT, (2) secara parsial menganalisis pengaruh komitmen organisasional terhadap kualitas pelayanan Bank NTT, (3) secara parsial menganalisis pengaruh perilaku kepemimpinan terhadap kualitas pelayanan Bank NTT, (3) secara bersama-sama menganalisis pengaruh komitmen organisasional dan perilaku kepemimpinan terhadap kualitas pelayanan Bank NTT. Hasil penelitian menunjukkan bahwa Bank NTT merupakan lembaga keuangan yang memiliki peranan penting dalam pembangunan di NTT yaitu menerima, menyimpan, dan menyalurkan dana kepada masyarakat dengan berbagai layanan produk dan jasa seperti giro, tabungan, kredit dan menjalankan tanggungjawab sosial perusahaan, serta layanan jasa perbankan antara lain ATM, mobile banking dan sms banking. Di samping itu, Bank NTT juga menyerap tenaga kerja sebanyak 1.228 orang tahun 2014, dengan jumlah nasabah 824.260 orang tahun 2014, serta memiliki 126 unit kantor tersebut di seluruh kabupaten/kota di NTT. Berdasarkan analisis diperoleh hasil bahwa secara parsial variabel kualitas pelayanan Bank NTT secara signifikan dipengaruhi komitmen organisasional (X1) yaitu sebesar sebesar 0,563 $(56,30 \%)$, berarti $43,70 \%$ dipengaruhi oleh variabel lain. Selanjutnya, hasil analisis parsial menunjukkan bahwa perilaku kepemimpinan (X2) memiliki pengaruh yang positif dan signifikan terhadap kualitas pelayanan Bank NTT ialah sebesar 0,656 $(65,6 \%)$, dan sisanya sebesar $34,4 \%$ dipengaruhi oleh variabel lain yang tidak dimodelkan dalam penelitian ini.
\end{abstract}

Kata Kunci: Komitmen, Organisasional, perilaku kepemimpinan, kualitas pelayanan.

\section{PENDAHULUAN}

Bank seyogianya terus berupaya meningkatkan kualitas pelayanan terhadap pelanggannya karena bank dalam operasinya sejatinya menghadapi persaingan ketat. Adanya kecenderungan daya saing yang cukup ketat dalam dunia bisnis dan keuangan mendorong suatu bank mesti dapat mempertahankan kualitas pelayanan dan menjaga stabilitas juga tingkat kesehatannya (Kasmir, 2008). Demikian halnya Bank NTT dalam operasinya mengusung semboyan utama ialah "melayani dengan sungguh" yang merupakan manifestasi budaya pelayanan (Publikasi Nasional Bank NTT, 2012). Sebagai Bank daerah, manajemen Bank NTT menjamin bahwa kebutuhan pelanggan telah diidentifikasi, dimasukkan ke dalam persyaratan kualitas pelayanan, operasional serta pembelajaran dan pertumbuhan, dan dipenuhi kebutuhannya untuk meraih kepuasan pelanggan $100 \%$ melalui perbaikan proses secara terusmenerus. BANK NTT mengikuti peraturan yang relevan dan persyaratan yang resmi dari Standar Kualitas Internasional ISO 
9001:2008.ISO 9001:2008 adalah standar international yang digunakan untuk menetapkan kebijakan dan sasaran mutu (quality objective). Proses Sertifikasi kesesuaian sistem mutu organisasi terhadap persyaratan standar seri ISO 9001:2008 dilakukan dengan tahapan berikut: (1) Pendefinisian ruang lingkup sertifikasi, (2) Kunjungan pendahuluan dilakukan untuk melihat gap analisis dan diagnosis antara standar yang diterapkan oleh organisasi terhadap ISO 9001:2008. Selanjutnya dilakukan audit sertifikasi yang terdiri atas 2 (dua) tahap yaitu tahap 1:Audit Pendahuluan yakni audit dokumen dan pre-audit untuk menguji tingkat penerapan sistem manajemen mutu ISO 9001:2008 di organisasi, guna persiapan pelaksanaan Audit Sertifikasi. Tahap2: Audit Sertifikasi ialah audit komprehensif untuk menilai efektivitas penerapan sistem manajemen mutu berdasarkan sistem dokumentasi yang telah dibuat dan ruang lingkup aplikasi sistem manajemen mutu.

Manajemen BANK NTT juga menjamin pemenuhan kepuasaan pelanggan dengan menetapkan dan meninjau-ulang tujuan-tujuan kinerja yang berhubungan dengan kepuasan pelanggan dalam Rapat Peninjauan-ulang Manajemen (Management Review Meeting). Bank NTT telah menetapkan Kebijakan Kualitas yang relevan dengan visi organisasi yang sesuai dengan persyaratan ISO 9001:2008. Kebijakan Kualitas ini dikomunikasikan ke seluruh anggota organisasi BANK NTT. Hasil penilaian kinerja pelayanan Kantor Cabang Utama tahun 2013 dari aspek fisik berada kondisi baik, aspek security baik, aspek customer service baik, aspek teller cukup baik. Sedangkan hasil penilaian kinerja pelayanan oleh Bank NTT sendiri pada Kantor Cabang Khusus (KCK) pada aspek aspek security kurang baik, customer service kurang baik, dan aspek teller cukup baik. Selanjutnya, penilaian kinerja pelayanan tahun 2014 mengalami perbaikan, yaitu Kantor Cabang Utama pada aspek fisik berada skala baik, aspek security baik, aspek customer service baik, aspek teller cukup baik. Sedangkan hasil penilaian kinerja pelayanan pada Kantor Cabang Khusus (KCK) pada aspek fisik baik, aspek security cukup baik, customer service kurang baik, dan aspek teller cukup baik sebagaimana disajikan dalam tabel 1 . berikut:

Tabel 1.

Hasil Penilaian Kinerja Pelayanan Kantor Cabang Utama dan Kantor Cabang Khusus Tahun 2013 - 2014

\begin{tabular}{|c|c|c|c|c|c|}
\hline \multirow[b]{2}{*}{ TAHUN } & \multirow[b]{2}{*}{ KANTOR } & \multirow[b]{2}{*}{$\begin{array}{c}\text { ASPEK } \\
\text { FISIK }\end{array}$} & \multicolumn{3}{|c|}{ ASPEK PEOPLE } \\
\hline & & & SECURITY & $\begin{array}{c}\text { Customer } \\
\text { Service }\end{array}$ & Teller \\
\hline \multirow[t]{2}{*}{2013} & $\begin{array}{c}\text { KCU } \\
\text { Kupang }\end{array}$ & Baik & Baik & Baik & $\begin{array}{c}\text { Cukup } \\
\text { Baik }\end{array}$ \\
\hline & $\begin{array}{c}\text { KCK } \\
\text { Kupang } \\
\end{array}$ & $\begin{array}{c}\begin{array}{c}\text { Kurang } \\
\text { Baik }\end{array} \\
\end{array}$ & Kurang Baik & $\begin{array}{c}\text { Kurang } \\
\text { Baik }\end{array}$ & $\begin{array}{c}\text { Cukup } \\
\text { Baik }\end{array}$ \\
\hline \multirow[t]{2}{*}{2014} & $\begin{array}{c}\mathrm{KCU} \\
\text { Kupang }\end{array}$ & Baik & Baik & Baik & Baik \\
\hline & $\begin{array}{c}\text { KCK } \\
\text { Kupang }\end{array}$ & Baik & Cukup Baik & Baik & $\begin{array}{c}\text { Cukup } \\
\text { Baik }\end{array}$ \\
\hline
\end{tabular}

Sumber: Bank NTT Pusat tahun 2015

Selain gambaran kinerja kualitas pelayanan yang dikemukakan tersebut, hasil observasi di kantor Kas Bank NTT Undana ditemukan pula indikasi masalah bahwa kualitas pelayanan belum sepenuhnya berjalan dengan baik. Hal tersebut terlihat pada fenomena pelayanan kepada nasabah seperti mahasiswa misalnya masih terdapat banyak mahasiswa yang belum dilayani dengan baik. Perkembangan dalam tehnologi seharusnya Bank NTT juga secara sistem dapat melayani pembayaran SPP mahasiswa Undana melalui ATM (Anjungan Tunai Mandiri), Bank NTT sendiri mempunyai standar pelayanan misalnya dalam transaksi setor tunai \pm 1 menit dan 30 detik/orang, perhitungan uang \pm 1 menit di atas 5 juta/orang untuk satu kali transaksi atau melayani satu orang nasabah. Dalam satu hari mahasiswa yang menyetorkan uang SPP berdasarkan hasil observasi sebanyak 600 mahasiswa atau lebih, dengan demikian maka terjadilah penumpukan nasabah dan antrian yang panjang, pelayanan registrasi on line melewati batas waktu yang ditentukan, sehingga dilakukan perpanjangan masa registrasi. Dalam hal pelayanan pembayaran gaji misalnya, sampai dengan 
saat ini sistem pembayaran gaji pemerintahan oleh Bank NTT masih melalui bendahara dan penerimaan secara tunai, bukan melalui transfer atau langsung masuk ke rekening Pegawai Negeri sipil yang bersangkutan. Penelitian ini difokuskan pada "Komitmen Organisasional dan Perilaku Kepemimpinan yang diduga berpengaruh terhadap Kualitas Pelayanan Bank NTT".

\section{KAJIAN TEORI}

\section{Bank Pembangunan Daerah Berfungsi Sebagai Agen Pembangunan (Agent of Development).}

Sebagaimana diketahui dalam kerangka pilar 1 arsitektur perbankan Indonesia, Bank Indonesia bersama Asbanda dan BPD seluruh Indonesia yang tergabung dalam kelompok kerja, telah menyelesaikan program transformasi BPD melalui penguatan daya saing dan kelembagaan BPD. Melalui program tersebut diharapkan BPD efektif melaksanakan fungsi sebagai agen pembangunan (agent of development) (Booklet Perbankan Indonesia, 2012). Bank sebagai agen pembangunan (agent of development), menjalankan fungsi memobilisasi dana untuk pembangunan ekonomi. Kegiatan bank berupa penghimpun dan penyalur dana sangat diperlukan bagi lancarnya kegiatan perekonomian di sektor riil. Kegiatan bank tersebut memungkinkan masyarakat melakukan kegiatan investasi, kegiatan distribusi, serta kegiatan konsumsi barang dan jasa, mengingat bahwa kegiatan investasi, distribusi dan konsumsi tidak dapat dilepaskan dari adanya penggunaan uang. Kelancaran kegiatan investasi, distribusi, dan konsumsi ini tidak lain adalah kegiatan pembangunan perekonomian suatu masyarakat. Bank sebagai lembaga kepercayaan (agent of trust), yaitu lembaga yang landasannya kepercayaan. Dasar utama kegiatan perbankkan adalah kepercayaan (trust), baik dalam penghimpun dana maupun penyaluran dana. Masyarakat akan mau menyimpan dananya di bank apabila dilandasi kepercayaan. Bank juga bertindak sebagai lembaga pelayanan (agent of services) yaitu bank disamping melakukan kegiatan penghimpun dan penyalur dana, bank juga memberikan penawaran jasa perbankan yang lain kepada masyarakan.

\section{Kualitas Pelayanan}

Menurut Goesth dan Davis dalam Tjiptono (2004:51) bahwa kualitas diartikan "sebagai suatu kondisi dinamis dimana yang berhubungan dengan produk, jasa, manusia, proses dan lingkungan yang memenuhi atau melebihi harapan. Dalam konteks pelayanan Sutopo dan Sugiyanti (1997: 25) menyatakan pelayanan memiliki arti sebagai membantu menyiapkan (atau mengurus) apa yang diperlukan seseorang.

Salah satu pendekatan kualitas pelayanan yang banyak dijadikan acuan dalam riset pemasaran adalah model SERVQUAL (Service Quality) yang dikembangkan oleh Parasuraman, Zeithaml, dan Berry bahwa terdapat lima dimensi SERVQUAL sebagai berikut (Parasuraman et al, 1998) :(1).Tangibles, atau bukti fisik yaitu kemampuan suatu perusahaan dalam menunjukkan eksistensinya kepada pihak eksternal. Penampilan dan kemampuan sarana dan prasarana fisik perusahaan dan keadaan lingkungan sekitarnya adalah bukti nyata dari pelayanan yang diberikan oleh pemberi jasa, yang terdiri atas fasilitas fisik (gedung, gudang, dan lain sebagainya), perlengkapan dan peralatan yang dipergunakan (teknologi), serta penampilan pegawainya; (2).Reliability, atau kehandalan yaitu kemampuan perusahaan untuk memberikan pelayanan sesuai yang dijanjikan secara akurat dan terpercaya. Kinerja harus sesuai dengan harapan pelanggan yang berarti ketepatan waktu, pelayanan yang sama, untuk semua pelanggan tanpa kesalahan, sikap yang simpatik, dan dengan akurasi yang tinggi; 
(3).Responsiveness, atau ketanggapan yaitu suatu kemampuan untuk membantu dan memberi pelayanan yang cepat (responsif) dan tepat kepada pelanggan, dengan penyampaian informasi yang jelas. Membiarkan konsumen menunggu tanpa adanya suatu alasan yang jelas menyebabkan persepsi yang negatif dalam pelayanan; (4). Assurance, atau jaminan dan kepastian yaitu pengetahuan, kesopansantunan, dan kemampuan para pegawai perusahaan untuk menumbuhkan rasa percaya para pelanggan kepada perusahaan. Terdiri dari beberapa komponen antara lain komunikasi (communication), kredibilitas (credibility), keamanan (security), kompetensi (competence), dan sopan santun (courtesy); (5). Emphaty, yaitu memberikan perhatian yang tulus dan bersifat individual atau pribadi yang diberikan kepada para pelanggan dengan berupaya memahami keinginan konsumen. Suatu perusahaan mestilah memiliki empati, pengertian, dan pengetahuan tentang pelanggan, memahami kebutuhan pelanggan secara spesifik, serta memiliki waktu pengoperasian yang nyaman bagi pelanggan. Aspek-aspek kecepatan, ketepatan, kemudahan, dan keadilan menjadi alat untuk mengukur pelayanan yang berkualitas. Dengan demikian dimensi-dimensi kualitas pelayanan yang fokus perhatian dalam penelitian ialah bukti fisik (tangibles), kehandalan (reliability), ketanggapan (responsiveness), jaminan (assurance), dan empati (empathy) (Parasuraman, Zeithaml dan Berry, 1988; Reynoso dan Moores, 1995 dalam Samuel, 2011: 27). Pendekatan tersebut dikenal sebagai SERVQUAL sebagai model paling baik dalam mengukur kualitas pelayanan dalam dunia perbankan (Angur et al, 1999, dalam dalam Mei Mei Lau et al, 2013).

\section{Faktor - faktor Yang Mempengaruhi Kualitas Pelayanan}

Berdasarkan hasil penelitian terdahulu dan telaah teori dapat dinyatakan bahwa terdapat banyak faktor yang mempengaruhi atau yang berkorelasi dengan kualitas pelayanan. Kualitas pelayanan berkaitan dengan komitmen organisasi (Malhotra dan Murkhejee, 2004), harapan dan kepuasan pelanggan (Kumbhar, 2011); perilaku kepemimpinan, komitmen organisasional, dan kepuasan kerja, (Samuel, 2011), kualitas pelayanan mempengaruhi citra perusahaan, loyalitas pelanggan, dan kepuasan nasabah (Chun et al., 2014). Chanming dan Jianjun (2011), kualitas pelayanan memiliki pengaruh terhadap loyalitas pelanggan (Mosahad et al, 2010), perilaku kepemimpinan/gaya kepemimpinan, dan komitmen karyawan (Asgari, 2014), gaya kepemimpinan (Farrel dan Souchon, 2001).

\section{multi dimensi (the multi dimensional approach).}

Allen dan Meyer (1997 dalam Jaros, 2007:7) merumuskan tiga komponen yang mempengaruhi komitmen organisasi sehingga karyawan memilih tetap atau meninggalkan organisasi berdasarkan norma yang dimilikinya. Tiga komponen tersebut adalah:

1. Affective commitment, berkaitan dengan adanya keinginan untuk terikat pada organisasi. Individu menetap dalam organisasi karena keinginannya sendiri. Kunci dari komitmen ini adalah want to. Dalam tipe komitmen ini, individu merasakan adanya kesesuaian antara nilai pribadinya dan nilai-nilai organisasi.

2. Continuance commitment, merupakan suatu komitmen yang didasarkan akan kebutuhan rasional. Dengan kata lain komitmen ini terbentuk atas dasar untung rugi, dipertimbangkan atas apa yang harus dikorbankan bila akan menetap pada organisasi. Kunci dari 
komitmen ini adalah kebutuhan untuk bertahan (need to). Komitmen tipe ini lebih mendasarkan keterikatannya pada cost benefit analysis.

3. Normative commitment, adalah komitmen yang didasarkan pada norma yang ada dalam diri karyawan, berisi keyakinan individu akan tanggung jawab terhadap organisasi. Ia merasa harus bertahan karena loyalitas. Kunci dari komitmen ini adalah kewajiban untuk bertahan dalam organisasi (ought to). Tipe komitmen ini lebih dikarenakan nilai-nilai moral yang dimiliki karyawan secara pribadi.

\section{Perilaku Kepemimpinan Berdasarkan Path-Goal Theory}

Perilaku kepemimpinan berdasarkan Path-Goal Theory (Samuel, 2011:8) dikategorikan atas dimensi perilaku kepemimpinan ialah : (1) Kepemimpinan direktif/petunjuk atau perintah (directive leadership) (berorientasi struktur dan tugas) mengarahkan bawahan tentang apa yang mesti dilaksanakan; melaksanakan pengawasan yang ketat terhadap pekerja, melakukan inspeksi kinerja karyawan, menyatakan apa yang mesti dilaksanakan, serta menggariskan apa yang menjadi peran dari karyawan, penetapan standarisasi perilaku, kurang mempercayai bawahan, dan tidak melibatkan para karyawan dalam pengambilan keputusan, (2) Kepemimpinan yang bersifat mendorong (supportive Leadership) (berorientasi pada karyawan atau mempertimbangkan karyawan sebagai mitra). Kepemimpinan mendorong memberikan perhatian apa yang menjadi kebutuhan karyawannya;

Kepemimpinan Partisipatif (participative leadership) ialah kepemimpinan yang melibatkan semua karyawan dari berbagai jenjang dalam organisasi dalam pengambilan keputusan dan pengimplementasian keputusan (Dorfman dan Gupta, 2004, Samuel, 2011). Kepemimpinan partisipatif memandang karyawan sebagai sumber masukkan dalam pengambilan keputusan, nilai lainnya ialah sebagai sumber pandangan, serta cenderung toleran terhadap perbedaan. Dengan demikian maka perilaku kepemimpian berfokus pada sejumlah perilaku pemberi petunjuk/perintah, mendorong/memotivasi, dan partisipatif dalam artian melibatkan karyawan dalam pengambilan keputusan dan pelaksanaan.

\section{METODE PENELITIAN}

Tipe penelitian adalah penelitian survey eksplanatif kuantitatif. Lokasi penelitian adalah Kantor Cabang Khusus dan Kantor Cabang Utama Bank NTT. Pemilihan Bank NTT Kantor Cabang Khusus, dan Cabang Utama didasari pada pertimbangan bahwa adanya penerapan Standar Kualitas Internasional ISO 9001: 2008, yang terdiri persyaratan 8 klausul ISO 9001:2008 ialah: (1) Ruang lingkup; (2) Rujukan normatif, (3) Istilah dan definisi, (4) Sistem manajemen mutu, (5) Tanggung jawab manajemen, (6) Manajemen sumber daya, (7) Realisasi produk, (8) Pengukuran, yang dimulai dari kedua kantor dimaksud. Selain itu, Bank NTT juga memperoleh berbagai penghargaan dan pengakuan kinerja berupa Award's dari sejumlah Instansi Nasional \& Lembaga Perbankan telah diterima oleh Bank NTT selama tahun 2014 (Press Release Kinerja PT Bank NTT Tahun Buku 2014)

Variabel penelitian terdiri atas variabel dependen ialah Kualitas Pelayanan diberi simbol Y, Variabel dependen ini merupakan variabel yang dipengaruhi atau yang menjadi akibat, karenanya disebut variabel bebas Sugiyono (2013). dan variabel independen terdiri atas Komitmen Organisasional diberi simbol (X1) dan Perilaku Kepemimpinan (X2).

Data yang dibutuhkan adalah data primer yang diperoleh langsung dari subyek penelitian sebagai responden yaitu karyawan PT. Bank NTT bagian pelayanan dengan mengacu pada daftar pertanyaan 
penelitian yang ada. Pengumpulan data dalam penelitian ini menggunakan beberapa teknik yaitu: a) Pertanyaan, b) Wawancara, c) Studi dokumen, dan d) Observasi.

Populasi penelitian adalah karyawan

Bank NTT yang memberikan pelayanan kepada nasabah pada Bank NTT Kantor Cabang Khusus dan Kantor Cabang Utama. Tercatat jumlah karyawan Bank NTT posisi laporan Bank NTT tahun 2014 sebanyak 1.228 orang, dan 824.260 nasabah (Press Release Kinerja PT Bank NTT Tahun Buku 2014). Sementara, untuk kantor Cabang Khusus PT. Bank NTT bagian pelayanan sebanyak 30 karyawan, dan kantor cabang Utama PT. Bank NTT bagian pelayanan sebanyak 19 karyawan. Dengan demikian jumlah karyawan bagian pelayanan (Kantor Cabang Khusus PT. Bank NTT + Kantor Cabang Utama PT. Bank NTT) sebanyak 49 karyawan sebagai sampel penelitian. Teknik sampling yang digunakan ialah cacah lengkap/sampel jenuh. Unit analisis dalam penelitian ini ialah karyawan bagian pelayanan Kantor Cabang Khusus PT. Bank NTT dan karyawan bagian pelayanan Kantor Cabang Utama PT. Bank NTT.

analisis data kuantitatif dengan pendekatan regresi untuk menganalisis pengaruh variabel independen terhadap variabel dependen dengan alat bantu SPSS. Analisis regresi dipergunakan untuk menelaah hubungan antara dua variabel atau lebih, terutama untuk menelusuri pola hubungan yang modelnya belum diketahui dengan sempurna. Regresi yang terdiri dari satu variabel bebas (predictor) dan satu variabel terikat (Response/Criterion) disebut regresi linier sederhana (bivariate regression), sedangkan regresi yang variabel bebasnya lebih dari satu disebut regresi berganda (Multiple regression/multivariate regression), yang dapat terdiri dari dua prediktor (regresi ganda) yaitu komitmen organisasional (X1) dan perilaku kepemimpinan (X2) dan kualitas pelayanan (Y).

$\mathbf{Y}=\mathbf{a}+\mathbf{b} \mathbf{X}_{1}+\mathbf{X}_{2}$ dimana:

$\mathrm{Y}=$ Kualitas Pelayanan

$\mathrm{X}_{1}=$ Variabel bebas 1 komitmen organisasional

$\mathrm{X}_{2}=$ Variabel bebas 2 perilaku kepemimpinan

\section{HASIL DAN PEMBAHASAN}

\section{Pengaruh Komitmen Organisasional Terhadap Kualitas Pelayanan Bank NTT}

Kualitas pelayanan mengacu pada model SERVQUAL (Service Quality) yang dikembangkan oleh Parasuraman, Zeithaml, dan Berry (1998) terdiri atas (1).Tangibles, (2).Reliability,

(3).Responsiveness, atau ketanggapan (4).Assurance, atau jaminan (5). Emphaty, Sementara komitmen organisasional mengacu pandangan Allen dan Meyer (1997) terdiri atas tiga komponen yang mempengaruhi komitmen organisasional sehingga karyawan memilih tetap atau meninggalkan organisasi berdasarkan norma yang dimilikinya. Tiga komponen tersebut adalah: (1) Affective commitment, berkaitan dengan adanya keinginan untuk terikat pada organisasi. (2) Continuance commitment, merupakan suatu komitmen yang didasarkan akan kebutuhan rasional. (3) Normative commitment, adalah komitmen yang didasarkan pada norma yang ada dalam diri karyawan.

Berdasarkan hasil analisis diperoleh pemahaman bahwa variabel kualitas pelayanan (Y) Bank NTT secara signifikan dipengaruhi komitmen organisasional (X1) yaitu sebesar sebesar 0,563 (56,30\%), berarti 43,70 persen dipengaruhi oleh variabel lain. Hasil analisis ini sejatinya mendukung pandangan dan berbagai hasil penelitian terdahulu. Hasil analisis ini searah dengan pandangan Sergeant dan Frenkel (2000) yang menyatakan bahwa komitmen organisasional karyawan frontline memiliki peranan penting dalam menentukan jenjang kualitas pelayanan yang diberikan kepada nasabah. Hasil penelitian ini mendukung pula temuan penelitian Hasbullah (2008) bahwa 
komitmen karyawan terkait erat dengan kinerja kualitas pelayanan dalam koperasi masyarakat di Peninsular Malaysia. Demikian pula hasil analisis ini memperkuat temuan penelitian Samuel (2011) yang menyatakan bahwa terdapat hubungan yang positif dan signifikan antara kualitas pelayanan dengan komitmen organisasional pada bank-bank komersial di Uganda - Kasus Distrik Kampala.

Sebaliknya, hasil analisis penelitian ini bertolak belakang dengan temuan penelitian (Maholtra dan Mukherjee, 2003) yang berpendapat bahwa dimensi afektif, kontinuans, dan normatif dari komitmen organisasional memiliki hubungan yang berbeda dengan dengan kualitas pelayanan. Hanya dimensi afektif dari komitmen organisasional yang memiliki hubungan yang erat dengan kualitas pelayanan, sedangkan dimensi-dimensi kontinuans dan normatif dari komitmen organisasional memiliki hubungan yang lemah dengan kualitas pelayanan. Temuan penelitian ini juga bertolak belakang dengan pandangan (Meyer dan Allen, 1991) yang menyatakan bahwa komitmen normative organisasional tidak mempengaruhi kualitas pelayanan secara signifikan.

\section{Pengaruh Perilaku Kepemimpinan terhadap kualitas Pelayanan Bank NTT.}

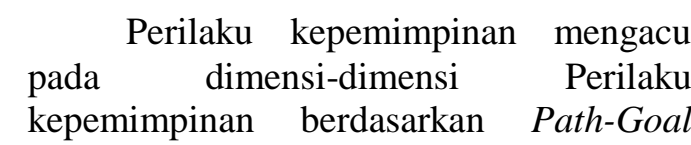
Theory (Samuel, 2011:8) dikategorikan atas dimensi perilaku kepemimpinan ialah : (1) Kepemimpinan direktif/petunjuk atau perintah (directive leadership) (berorientasi struktur dan tugas), (2) Kepemimpinan yang bersifat mendorong (Supportive Leadership) (berorientasi pada karyawan atau mempertimbangkan karyawan sebagai mitra), (3) Kepemimpinan Partisipatif (Participative Leadership) ialah kepemimpinan yang melibatkan semua karyawan dari berbagai jenjang dalam organisasi dalam pengambilan keputusan dan pengimplementasian keputusan (Dorfman dan Gupta, 2004, Samuel, 2011). Sementara, kualitas pelayanan didasarkan pandangan Parasuraman, Zeithaml, dan Berry (1998) terdiri atas
(1).Tangibles,
(2). Reliability,

(3).Responsiveness, atau ketanggapan

(4).Assurance, atau jaminan (5). Emphaty.

Hasil analisis menunjukkan bahwa perilaku kepemimpinan (X2) memiliki pengaruh yang positif dan signifikan terhadap kualitas pelayanan (Y) Bank NTT ialah sebesar 0,656 (65,6\%), dan sisanya sebesar $34,4 \%$ dipengaruhi oleh variabel lain yang tidak dimodelkan dalam penelitian ini. Hasil penelitian ini mendukung pandangan Lussier dan Achua (2001), dan Samuel (2011) bahwa perilaku kepemimpinan memiliki hubungan yang positif dan signifikan terhadap kinerja kualitas pelayanan. Menurut Lussier dan Achua (2001) perilaku kepemimpinan lebih gampang untuk belajar dan melakukan perubahan termasuk pula dalam hal peningkatan kualitas pelayanan ketimbang ciri-ciri kepemimpinan. Temuan penelitian ini juga searah dengan hasil penelitian Zeithaml dan Bitner (1996), Farrel dan Souchon (2001) yang menemukan bahwa kepemimpinan mempengaruhi kualitas pelayanan. Namun penelitian ini bertolak belakang dengan hasil penelitian Chen dan Liu (tanpa tahun), dan penelitian Jabnoun dan Al Rasasi (2005) yang menemukan bahwa gaya kepemimpinan tidak signifikan dan berkorelasi negatif dengan kualitas pelayanan.

\section{Pengaruh Komitmen Organisasional dan Perilaku Kepemimpinan Secara Simultan Terhadap Kualitas Pelayanan Bank NTT}

Hasil analisis diperoleh nilai pengaruh secara bersama-sama antara komitmen organisasional (X1) dan perilaku kepemimpinan (X2) terhadap kualitas pelayanan Bank NTT (Y) sebesar 0,710 . Hasil penelitian ini berarti terdapat 
pengaruh yang signifikan antara komitmen organisasional (X1) dan perilaku kepemimpinan (X2) terhadap kualitas pelayanan Bank NTT (Y) sebesar 71 persen, sementara 29 persen dipengaruhi oleh variabel lain yang tidak dimodelkan dalam penelitian ini. Model persamaan yang diperoleh dari hasil perhitungan regresi berganda dapat disajikan dalam formula berikut $\mathrm{Y}=\mathbf{1 5 . 4 1 4}+\mathbf{0 . 3 1 2} \mathrm{X1}+$ 0.499X2. Persamaan ini dapat digunakan untuk memprediksikan pengaruh komitmen organisasional dan perilaku kepemimpinan terhadap kualitas pelayanan Bank NTT.

Hasil penelitian ini mendukung temuan penelitian Samuel (2011) yang menyatakan bahwa perilaku kepemimpinan, dan komitmen organisasional serta kepuasan kerja secara keseluruhan memperbaiki kualitas pelayanan bank. Kualitas pelayanan telah menjadi perhatian utama karena menentukan keberlanjutan dan perkembangan perbankan dalam era persaingan saat ini (Wang, dkk, 2003). Sementara faktor-faktor lain (29\%) yang mempengaruhi kualitas pelayanan ialah information communication technology (ICT) (Khumbar V.M, 2011), komitmen manajemen dan pelatihan (Tavitiyaman, 2004), peranan kepemimpinan dan komitmen terhadap TQM dalam pelayanan organisasi (Mustafa dan Bon, 2012), Kepuasan kerja (Samuel, 2011), gaya kepemimpinan, komitmen karyawan dan kepuasan kerja (Asgari, 2014). Dalam konteks penelitian kualitas pelayanan bank NTT, sebagaimana diketahui bahwa peranan ICT diwujudkan dalam bentuk pelayanan anjungan tunai mandiri (ATM) memungkinkan para nasabah dapat melakukan transaksi tunai (penarikan tunai) dalam batas tertentu setiap kali penarikan pada ATM Bank NTT atau ATM bersama.

\section{SIMPULAN}

Mengacu hasil penelitian dan pembahasan sebagaimana dipaparkan pada bagian terdahulu, selanjutnya dapat dikemukakan beberapa simpulan berikut:

a. Eksistensi Bank NTT memiliki peranan penting dalam pembangunan di Provinsi Nusa Tenggara Timur. Sebagai lembaga keuangan milik pemerintah dan masyarakat Nusa Tenggara Timur khususnya, dan masyarakat Indonesia umumnya berperan dalam hal menarik dana masyarakat, menyimpan, dan menyalurkan kepada berbagai pihak yang membutuhkan, turut membiayai proyek pembangunan, melaksanakan tanggungjawab sosial, membuka lapangan pekerjaan, dan sebagai salah sumber pendapatan asli daerah (PAD).

b. Komitmen organisasional secara parsial memiliki pengaruh yang positif dan signifikan terhadap kualitas pelayanan Bank NTT.

c. Perilaku kepemimpinan secara parsial memiliki pengaruh yang positif dan signifikan terhadap kualitas pelayanan Bank NTT.

d. Komitmen organisasional dan perilaku kepemimpinan secara simultan memiliki pengaruh yang positif dan signifikan terhadap kualitas pelayanan Bank NTT.

\section{DAFTAR PUSTAKA}

Asgari, Mohammad Reza., (2014), The Effect of Leadership Styles On Employees Commitment To Services Quality In Bank Melli Branches of Isfahan, Kuwait Chapter of Arabian Journal of Business and Management Review Vol. 3, No.12; August. 2014

Bank NTT, (2011), Laporan Keuangan Tahunan PT. Bank Pembangunan Daerah Nusa Tenggara Timur, http: //www. bpdntt. co.id /index. php/ id/ 
content /index /40201, diakses 01 Maret 2015

Bank Indonesia, (2012), Booklet Perbankan Indonesia, Jakarta

Bank NTT, (2012)., Laporan Keuangan Tahunan PT. Bank Pembangunan Daerah Nusa Tenggara Timur, Publikasi Nasional.

Chun-Chen Huang, Szu-Wei Yen, ChengYi Liu, Te-Pei Chang. (2014)., Exploring The Relations Between Service Quality And Consumer, http://www.ijoionline.org/attachments/article/38/FI NAL ISSUE VOL 6 NUM 3 JA NUARY_2014.pdf, diakses 03 Maret 2015

Farrell., Andrew M.Anne L. Souchon.Geoff R. Durden; (2001)., The Effect of Leadership Styles on Service Quality Delivery, Academy of Marketing 2001 - Research-inProgress Paper,

Gana, Frans, 2011., Kreasi Pengetahuan, Inovasi dan Daya Saing Bisnis (Bunga Rampai), Penerbit Universitas Indonesia, Jakarta.

Hasbullah, N.B. (2008). The Relationship between Leadership Behaviour and Organizational Commitment: A Study in The Co-operative Societies in Peninsular

Jaros, Stephen, (2007)., Meyer and Allen Model of Organizational Commitment: Measurement Issues, The Icfai University Press

Kasmir, S.E. M.M., (2008), Bank dan Lembaga Keuangan Lainnya, Edisi Revisi, Penerbit Rajawali Press

Khumbar, V.M (2011)., Factors Affecting The Customers Satisfaction In EBanking: Some Evidences From
Indian Banks, Management Research And Practice Vol.3 Issue 4 PP: 1 - 14 .

Lussier, Robert N. and Christopher F. Achua, (2001)., Leadership: Theory, Application, Skill Development, 1E, South-Western College Publishing

Malhotra, N. \& Mukherjee, A. (2004). The Relative Influence of Organizational Commitment and Job Satisfaction on Service Quality of Customer Contact Employeesin Banking Call Centres. Journal of Services Marketing 18, 3, 162-174.

Parasuraman, Voss, Glenn B. Dhruv Grewal (1998)., The Roles of Price, Performance, and Expectations in Determining Satisfaction in Service Exchanges, Journal of Marketing62(Oct), 4, 46-61

Samuel, Opolot Julius., 2011, Leadership Behaviour, Organisational Commitment, Job Satisfaction and Service Quality in Commercial Banks In Uganda A Case Of Kampala District, (Dissertation), Makerere University

Sutopo dan Sugiyanti, (1997)., Pelayanan Prima, Rineka Cipta, Jakarta 